\title{
Antimicrobial and antioxidant activities and volatile constituents of Eurhynchium angustirete (Broth.) T. J. Kop. and Isothecium alopecuroides (Lam. ex Dubois) Isov. from Turkey
}

\author{
Tayyibe Beyza YÜCEL ${ }^{1, *}$, (iD Hüseyin ERATA ${ }^{2}$ \\ ${ }^{1}$ Health Services Vocational School, Giresun University, 28200, Giresun, TURKEY \\ ${ }^{2}$ Bayramiç Vocational School, Çanakkale Onsekiz Mart University, 17700, Çanakkale, TURKEY \\ *Corresponding author. Email: beyza.yucel@giresun.edu.tr
}

Submitted: 10.07.2021; Accepted: 25.08.2021

\begin{abstract}
The aim of the present study was to determine the chemical analysis, antimicrobial and antioxidant effects of the Eurhynchium angustirete (Broth.) and Isothecium alopecuroides (Lam. Ex Dubois) essential oil obtained by distillation method (Clevenger apparatus hydrodistillation). Obtained volatile oils were identified by gas chromatography-mass spectrometry (GC/MS) which revealed the presence of twenty-two components analyzed in the essential oil of $E$. angustirete representing $95.7 \%$ of the total identified compounds and twenty compounds were determined in the essential oil of $I$. alopecuroides representing $94.3 \%$ of the total identified compounds. Trans-pinocarveol and myrtenal as major constituents were $23.0 \%$ and $14.1 \%$ in E. angustirete and the main components were: biformene (9.9\%), $\alpha$-pinene (9.1\%), bornyl acetate (8.4\%) in I. alopecuroides. The essential oils from $E$. angustirete and $I$. alopecuroides showed higher metal-ion chelating activities which were $65.93 \pm 0.39 \%$ and $31.01 \pm 2.75$, respectively. There was no significant difference results DPPH activity of essential oils $16.8 \pm 6.98$ and $22.8 \% \pm 8.91$, respectively. The antimicrobial activity was investigated by microdiution method. The isolated essential oils were showed effective antimicrobial activities against Escherichia coli ATCC25922, Enterococcus faecalis ATCC29212, Staphylococcus aureus ATCC25923, Pseudomonas aeruginosa ATCC2785 and Streptococcus mutans. Antimicrobial effect values were found ranging of 90.76-95.38\%. According to antimicrobial effect value against to microorganism, essential oil of E. angustirete was higher than I. alopecuroides.
\end{abstract}

Keywords: Mosses, essential oil, GC/MS, antimicrobial activity, antioxidant activity.

\section{Introduction}

Bryophyta (mosses, 14000 species) belongs to Bryophytes have about 23000 species in the worldwide comprise the second largest group of plants after angiosperms (Asakawa et al., 2013; Asakawa and Ludwiczuk, 2017). Bryophytes have spread all over the world except the sea. (Vollar et al., 2018; Önder and Özenoğlu, 2019). Bryophytes play a valuable role in maintaining ecosystems because they have the dense cuticle layer which holds the water and have partitions in their structure which protect the insect into. The mosses are represented by approximately 25000 taxa around the world (Smith, 2004). In previous studies, although there are many studies are about usually biomonitoring/bioindicator of waters and air pollution in addition to its use for determination of heavy metal accumulation for mosses, photochemical structures and biological activity of mosses studies have been limited (Yushin et al., 2020; Matos et al. 2021; Limpens et al., 2017)

Mosses as Rhodobryum, Bryum and Philonotis genus have been used as traditional medicine to reduce the risk of infection from burns, wounds and cuts in countries such as North American Indians and China (Glime, J.M. 2007; Harborne, J.B. 1998). Recently, it has attracted great attention from scientists for pharmacology and drug discovery due to mosses can be a source of metabolites. Previously, there are several studies about antibacterial, antifungal, antiviral, antioxidant, insecticidal, cytotoxic and antitumor activity against some cell cancer extracts of many species Bryophyta (Cheng et al., 2013; Onbaşlı and Yuvalı, 2021). Terpenoid compounds, which are intensely determined in essential oils extracted from plants, have 
many biological activities. Among these compounds, monoterpenoids containing two isoprene units were identified as compounds such as $\beta$-cyclocitral, 6 -ionone, geosmin and $\alpha$-pinene which were most detected in the essential oils of mosses. Moreover, sesqui- and diterpenoids including respectively three and four isoprene units isolated from some mosses represented cytotoxic activity against cancer cells such as momilactones A and B from the moss Hypnum plumaeforme (Hypnacea) (Chen et al., 2018). Lately mosses have begun to attract great interest from the field of chemistry research in search of a source of new and/or bioactive compounds in pharmacology and for drug discovery.

In Turkey, there are three species of Isothecium genus belong Lembophyllaceae family, and two species of Eurhynchium genus belong Brachytheciaceae family. In one of the previous studies about Isothecium alopecuroides species, it was observed that I. alopecuroides showed the highest effect in terms of the number of microorganisms it affected (Altuner, 2008). Other studies about this species generally were biomonitoring, metal accumulation and the epiphytic bryophyte flora (Alataş et al., 2015; Sun et al., 2007; Sert et al., 2011). Also, Eurhynchium angustirete was chosen as another moss species in this study, because there are a few reports on the antimicrobial activities of essential oil of Eurhynchium angustirete grown in different parts of the world including Turkey (Tosun et al., 2015; Nikolajeva et al., 2014).

In this study, the essential oils of Eurhynchium angustirete (Broth.) (E. angustirete) and Isothecium alopecuroides (Lam. Ex Dubois) (I. alopecuroides) were extracted by hydrodistillation (HD) using a Clevenger type apparatus and the variation in the essential oils were characterized by gas chromatography mass spectrometry (GC/MS). Moreover, antimicrobial activity of essential oils was identified by microdilution methods against to Escherichia coli ATCC25922, Enterococcus faecalis ATCC29212, Staphylococcus aureus ATCC25923, Pseudomonas aeruginosa ATCC27853 and Streptococcus mutans (clinical isolate). The antioxidant activity of essential oils was also examined by DPPH scavenging assay and metal-ion chelating assay. There are no previous reports on the chemical compositions, antimicrobial and antioxidant activity of the Isothecium alopecuroides volatile oils but in a previous study, chemical profile and antimicrobial activity of the essential oil of Eurhynchium angustirete has differences in terms of volatile compounds and microorganism, which can be explained by the environmentally, locality and the subspecies of the plant used (Altuner and Çetin 2018; Tosun et al. 2015).

\section{Materials and Methods}

\section{Plant material}

E. angustirete was collected on $5^{\text {th }}$ June 2018 from Erikbeli plateau with coordinate position (Lat. $\left.40^{\circ} 45^{\prime} 00.80^{\prime \prime} \mathrm{N} / 39^{\circ} 13^{\prime} 39.18^{\prime \prime E}\right)$, Tonya, Trabzon, at an altitude of $1440 \mathrm{~m}$. I. alopecuroides was collected from rocks and stony places in the Erikbeli plateau with coordinate position (Lat. $40^{\circ} 43^{\prime} 12.39^{\prime \prime} \mathrm{N} / 39^{\circ} 38^{\prime} 41.21^{\prime \prime E}$ ) at 848 meters in the centre of Tonya district of Trabzon, Turkey in May 2018, The voucher specimens were identified by Professor Batan, and deposited under number KTUB 1610, KTUB 1609 respectively, at the Herbarium of Department of Biology, Karadeniz Technical University, Trabzon, Turkey.

\section{Isolation of essential oil}

The collected fresh moss samples were cleaned to ward off insects if any and other soil particles. The fresh aerial parts of E. angustirete and I. alopecuroides were divided into smaller pieces. A sample weighing $30 \mathrm{~g}$ of each moss samples were subjected to hydro-distillation using a Clevenger-type apparatus for $4 \mathrm{~h}$ (yields: $0.05 \%(w / w), 0.08 \%(w / w)$, respectively). The obtained oils were dissolved in HPLC grade $n$-hexane $(0.5 \mathrm{~mL})$ 
and dried over anhydrous sodium sulphate and stored at $4-6{ }^{\circ} \mathrm{C}$ in a sealed brown vial. One $\mu \mathrm{L}$ of the essential oils was directly injected separately into GC and GC/MS instrument. The oils were dried over anhydrous sodium sulfate and preserved in a sealed vial at $4{ }^{\circ} \mathrm{C}$ until further analysis.

\section{GC/MS condition}

The GC/MS analysis was performed using Shimadzu 2010 Plus gas chromatograph coupled to a Shimadzu QP2010 Ultra mass selective detector. The separation was performed by means of a Restek Rxi-5MS capillary column, $60 \mathrm{~m}$ length, $0.25 \mathrm{~mm}$ i.d. and a $0.25 \mu \mathrm{m}$ phase thickness. The split mode was used. The oven program was as follows: Initial temperature was $60^{\circ} \mathrm{C}$ for $2 \mathrm{~min}$, which was increased to $240^{\circ} \mathrm{C}$ at $3{ }^{\circ} \mathrm{C}$ $\mathrm{min}^{-1}, 250^{\circ} \mathrm{C}$ was maintained for $4 \mathrm{~min}$. Helium (99.999\%) was used as carrier gas with a constant flow-rate of $1 \mathrm{~mL} \mathrm{~min}{ }^{-1}$. Detection was carried out in electronic impact mode (EI); ionization voltage was fixed to 70 eV. Scan mode $(40-450 \mathrm{~m} / \mathrm{z})$ was used for mass acquisition.

The volatile compounds were identified by comparison with their retention index (RIs)(relative to $\mathrm{C}_{7}-\mathrm{C}_{30} \mathrm{n}$ alkane standard) for identification (Adams, 2004). The mass spectral were compared value of the two libraries (FFNSC1.2 and W9N11) (Çelik, 2020).

\section{Antioxidant activity}

\section{Measurement of metal-ion chelating capacity}

The chelation of ferrous ions by the essential oils of each species was determined as the previous method (Decker and Welch, 1990). Different concentrations of essential oil $(25,50,100,200,400$, and $800 \mu \mathrm{g} / \mathrm{mL}$ ) were added to the reaction mixture as described by Decker and Welch. The absorbance of the reaction mixture was measured at $562 \mathrm{~nm}$. EDTA and Trolox were used as standards in the same concentration of essential oils. The percentage of chelating capacity of the test sample was calculated as follows:

$$
\text { Chelating capacity } \%=\left[\left(A_{1}-A_{2}\right) / A_{1} \times 100\right]
$$

where $A_{1}$ is the absorbance of control and $A_{2}$ is the absorbance in the presence of essential oil or EDTA.

\section{$D P P H^{\circ}$ scavenging activity assay}

The antioxidant activity of each species' essential oil was first determined by measuring the $\mathrm{DPPH}^{\circ}$ scavenging activity. The essential oil at various concentrations $(25,50,100,200,400$, and $800 \mu \mathrm{g} / \mathrm{mL}$ ) was added to the reaction mixture including $\mathrm{DPPH}^{\circ}$. When $\mathrm{DPPH}^{\circ}$ reacts with an antioxidant in the essential oil that can donate hydrogen, it gets reduced form and the resulting decrease in absorbance at $517 \mathrm{~nm}$ was recorded using a UV-Vis spectrophotometer (Jasco, V-630, Tokyo, Japan) (B. Williams et al., 1995). In this study, Trolox and BHT were used as antioxidant standards. DPPH scavenging activity of the test sample was calculated as follows:

$$
\mathrm{DPPH}^{\bullet} \%=100-\left(\mathrm{A}_{0}-\mathrm{A}_{1} / \mathrm{A}_{0} \times 100\right)
$$

\section{Antimicrobial activity}

Growth inhibitory activity of the essential oils were tested against Escherichia coli ATCC25922, Enterococcus faecalis ATCC29212, Staphylococcus aureus ATCC25923, Pseudomonas aeruginosa ATCC27853 and Streptococcus mutans (clinical isolate). Antimicrobial activity test was carried out according to the CLSI laboratory standard for broth microdilution assays (CLSI, 2012). For this purpose, antibiotic stock solutions were prepared for the antibiotic test and serial dilutions were made in separate tubes from here. An overnight culture on a nonselective medium such as bloody agar was used in the experiment. A standard 
inoculum of 0.5 McFarland units (108 colony forming units $/ \mu \mathrm{L}$ ) was prepared in MRS broth. It has diluted 1:30 (5x106 CFU/mL) and $50 \mu \mathrm{L}(2.5 \times 105 \mathrm{CFU} / \mathrm{mL})$ inoculated into each well excluding the control well. Therefore, bacteria inoculum of approximately $2.5 \times 105 \mathrm{CFU} / \mathrm{mL}$ was adjusted in a final volume of $100 \mu \mathrm{L}$ in each well. MRS was used in bacterial suspension and antibiotic dilutions were prepared by DMSO. A well of each plate was used as growth control and a well of each plate was used as a sterilization control and included only broth. The same antibiotics stock solutions and dilutions of the same antibiotics were analyzed on appropriate ATCC strains in another plate for quality control of the experiment. The plates were incubated at $35-37^{\circ} \mathrm{C}$ for 24 hours in a normal atmosphere. Ampicillin $(10.000 \mu \mathrm{g} / \mathrm{mL})$, fluconazole $(5.000 \mu \mathrm{g} / \mathrm{mL})$, and streptomycin $(10.000 \mu \mathrm{g} / \mathrm{mL})$ were used as standard antibacterial and antifungal. When MIC values of quality control strains were appropriate and the results of the growth control, the sterilization control, the inoculum purify control, and the inoculum density control was valid, the plates were read by a microplate reader in $600 \mathrm{~nm}$. The results obtained are calculated as $\%$ inhibition.

\section{Statistical analysis}

The obtained essential oils were tested for antioxidant and antimicrobial activities. A statistical package (SPSS version 20.0) was used for data analysis. The statistical analysis was performed using a one-way ANOVA $(p<0.05)$. Each biological activity test was done twice in duplicate and the results are expressed as mean \pm standart deviation (SD).

\section{Results and Discussion}

The essential oil compositions of E. angustirete and I. alopecuroides are listed in Table 1. As shown, twentytwo components, representing almost $95.7 \%$ of the essential oil of E. angustirete, were characterized. The major components were: pinocarveol (23.0\%), myrtenal (14.1\%) and verbenone (7.3\%). Üçüncü et al (2010) reported that Tortula muralis growing in the Gümüşhane region in Turkey contained pinocarveol (0.6\%), myrtenal $(0.7 \%)$ and verbenol $(0.8 \%)$. On the other hand, it was reported that Pseudoscleropodium purum growing in Artvin, Turkey contained pinocarveol (0.6\%) and myrtenal (0.8\%) (Tosun et al., 2015).

Thirty-one components were identified for I. alopecuroides (Table 1 ), representing almost $94.3 \%$ of total oils. The main components were determined as biformene (9.9\%), $\alpha$-pinene $(9.1 \%)$, bornyl acetate (8.4\%), respectively. Biformene, a labdane-type diterpene was reported in Bazzania francana which is a moss-like plant (Metoyer et al., 2018). It is known that the labdane diterpenes have been shown to possess cardiovascular effects, anti-fungal activity, and anti-inflammatory and cytotoxic effects (Singh et al., 1999; Demetzos et al., 2001; Lahlou et al., 2007). Also, 1-Heptatriacontanol (1.6\%) was detected in essential oil of I. alopecuroides. 1-Heptatriacontanol an alcoholic compound exhibit anti-hypercholesterolemic, antioxidant, anti-inflammatory, anticancer and antimicrobial effect (Baskaran et al., 2015; Kalaimagal, 2019).

Table 1. Chemical composition of essential oils of mosses

\begin{tabular}{llcccc}
\hline $\begin{array}{l}\text { Retention } \\
\text { time }\end{array}$ & Compounds & A \% & B \% & RI $^{[\mathrm{a}]}$ Liт & $\mathbf{R I}^{[\mathrm{b}]_{\text {EXP }}}$ \\
\hline & Monoterpenes & & & \\
6.66 & Tricyclene & - & 1.2 & 927 & 931 \\
6.90 & a-pinene & 4.3 & 9.1 & 932 & 935 \\
7.36 & Camphene & - & 4.1 & 956 & 961 \\
8.07 & Sabinene & - & 3.0 & 975 & 977 \\
8.30 & 6-pinene & 6.5 & 5.0 & 979 & 982
\end{tabular}




\begin{tabular}{|c|c|c|c|c|c|}
\hline 9.78 & Limonene & - & 1.2 & 1030 & 1035 \\
\hline 10.03 & Z-6-Ocimene & - & 1.7 & 1037 & 1042 \\
\hline 10.25 & E-B-Ocimene & 3.1 & 7.4 & 1050 & 1050 \\
\hline 11.94 & Terpinolene & 0.6 & - & 1089 & 1090 \\
\hline \multirow[t]{2}{*}{12.59} & Linalool & 0.8 & - & 1091 & 1095 \\
\hline & Oxyganeted monoterpenes & & & & \\
\hline 14.69 & trans-Pinocarveol & 23.0 & - & 1135 & 1140 \\
\hline 14.71 & trans-Limonene oxide & 1.4 & 1.8 & 1142 & 1141 \\
\hline \multirow[t]{2}{*}{18.24} & trans-Carveol & 1.5 & - & 1217 & 1220 \\
\hline & Oxygenated monoterpenes related & & & & \\
\hline 15.48 & Citronellal & 0.9 & - & 1153 & 1155 \\
\hline 15.72 & Pinocarvone & 3.6 & 1.3 & 1165 & 1162 \\
\hline 15.87 & Borneol & 2.4 & 2.0 & 1166 & 1167 \\
\hline 16.37 & Terpinen-4-ol & 5.9 & 1.1 & 1177 & 1178 \\
\hline 16.96 & $\alpha$-Terpineol & 2.2 & 1.1 & 1186 & 1192 \\
\hline 17.17 & Myrtenal & 14.1 & 1.7 & 1196 & 1195 \\
\hline 17.75 & Verbenone & 7.3 & 3.0 & 1207 & 1205 \\
\hline 21.08 & Bornyl acetate & 1.3 & 8.4 & 1289 & 1291 \\
\hline 26.63 & $\alpha$-Ionone & - & 0.9 & 1430 & 1432 \\
\hline \multirow[t]{2}{*}{28.47} & 8-Ionone & 0.4 & 1.5 & 1487 & 1492 \\
\hline & Sesquiterpenes & & & & \\
\hline 24.80 & $\alpha$-Copaene & 0.7 & 1.9 & 1375 & 1372 \\
\hline 26.35 & Trans-caryophyllene & - & 1.2 & 1418 & 1420 \\
\hline 27.10 & Z-6-Farnesene & 0.5 & - & 1443 & 1445 \\
\hline \multirow[t]{2}{*}{27.48} & $\alpha$-Humulene & - & 1.0 & 1452 & 1456 \\
\hline & Oxyganeted sesquiterpenes & & & & \\
\hline 31.22 & Caryophyllene oxide & 1.9 & 5.4 & 1582 & 1585 \\
\hline \multirow[t]{2}{*}{32.83} & $\alpha$-Cadinol & - & 1.3 & 1652 & 1650 \\
\hline & Oxygenated sesquiterpenoids related & & & & \\
\hline \multirow[t]{2}{*}{36.06} & Hexahydrofarnesyl acetone & - & 5.2 & 1844 & 1848 \\
\hline & Diterpenes & & & & \\
\hline \multirow[t]{2}{*}{41.53} & Biformene & - & 9.9 & 2026 & 2030 \\
\hline & Carboxyllic acids & & & & \\
\hline 37.23 & Pentadecanoic acid & - & 2.6 & 1871 & 1875 \\
\hline \multirow[t]{2}{*}{39.10} & cis-13-eicosenoic acid & - & 1.5 & 1915 & 1918 \\
\hline & Others & & & & \\
\hline 12.55 & 2-Nonanone & - & 2.3 & 1090 & 1093 \\
\hline 13.28 & Nonanal & & 2.5 & 1100 & 1101 \\
\hline 14.90 & $(2 E, 6 Z)$-Nonadienal & 13.3 & 2.4 & 1153 & 1148 \\
\hline \multirow[t]{11}{*}{42.37} & 1-Heptatriacontanol & - & 1.6 & 2303 & 2300 \\
\hline & Monoterpenes & 15.3 & 32.7 & & \\
\hline & Oxygenated Monoterpenes & 25.9 & 1.8 & & \\
\hline & Oxygenated Monoterpenes related & 38.1 & 21 & & \\
\hline & Sesquiterpenes & 1.2 & 4.1 & & \\
\hline & Oxygenated Sesquiterpenes & 1.9 & 6.7 & & \\
\hline & Oxygenated Sesquiterpenes related & - & 5.2 & & \\
\hline & Diterpene & - & 9.9 & & \\
\hline & Carboxyllic acid & - & 4.1 & & \\
\hline & Others & 13.3 & 8.8 & & \\
\hline & Total & 95.7 & 94.3 & & \\
\hline
\end{tabular}

aPercentages obtained by FID peak-area normalization. ${ }^{b} \mathrm{RI}$ calculated from retention times relative to that of $n$-alkanes $\left(C_{7}-C_{30}\right)$ on the non-polar Rxi-5MS column. A: E. angustirete, B: I. alopecuroides. 


\section{Antioxidant activity of essential oils}

Metals such as iron and copper prevent redox reactions that can occur in the biological system. Excessive accumulation of these metals causes many diseases such as DNA damage, lipid peroxidation and protein modification (Jomova and Valko, 2011). The chelation of redox-active metals prevents oxidative damage by preventing a redox reaction from occurring. In this study, maximum metal ion chelating activity was observed in E. angustirete and I. alopecuroides as the value of $31.01 \pm 2.75$ and $65.93 \pm 0.39$, respectively (Table 2).

The $\mathrm{DPPH}^{\bullet}$ method was performed by converting free radical DPPH to non-radical DPPH-H in the presence of a hydrogen-donating antioxidant and measuring the concentration of this compound at $517 \mathrm{~nm}$. Both species represented similar activity to reduce $\mathrm{DPPH}^{*}$ (Table 2 ). $\mathrm{DPPH}^{\bullet}$ activity was determined as value of $16.88 \pm 6.98$ and $22.84 \pm 8.91$, respectively. \pm values indicate the standard deviation. As a result of Anova test, no statistical significance was observed between samples in metal chelate data and DPPH ${ }^{\bullet}$ data $(p<0.953)$.

Table 2. DPPH ${ }^{\bullet}$ and metal ion-chelating activities of essential oils obtained from E. angustirete and I. alopecuroides (Inhibition\% \pm SD)

\begin{tabular}{lll}
\hline Samples & \% DPPH radical scavenging & \% Metal ion-chelating \\
\hline E. angustirete & $16.88 \pm 6.98$ & $31.01 \pm 2.75$ \\
I. alopecuroides & $22.84 \pm 8.91$ & $65.93 \pm 0.39$ \\
BHT & $94.69 \pm 0.04$ & - \\
Trolox & $90.57 \pm 0.06$ & - \\
EDTA & & $97.06 \pm 0.01$
\end{tabular}

aValues are given as mean \pm S.D. $(n=3)$, and there is no significantly different at $p<0.05$. ${ }^{b}$ Values are given as mean $\pm S . D .(n=3)$, and considered to be significantly different at $p<0.05$. BHT, Trolox and EDTA antioxidant standards

Figure 1. Metal chelating activity of essential oil

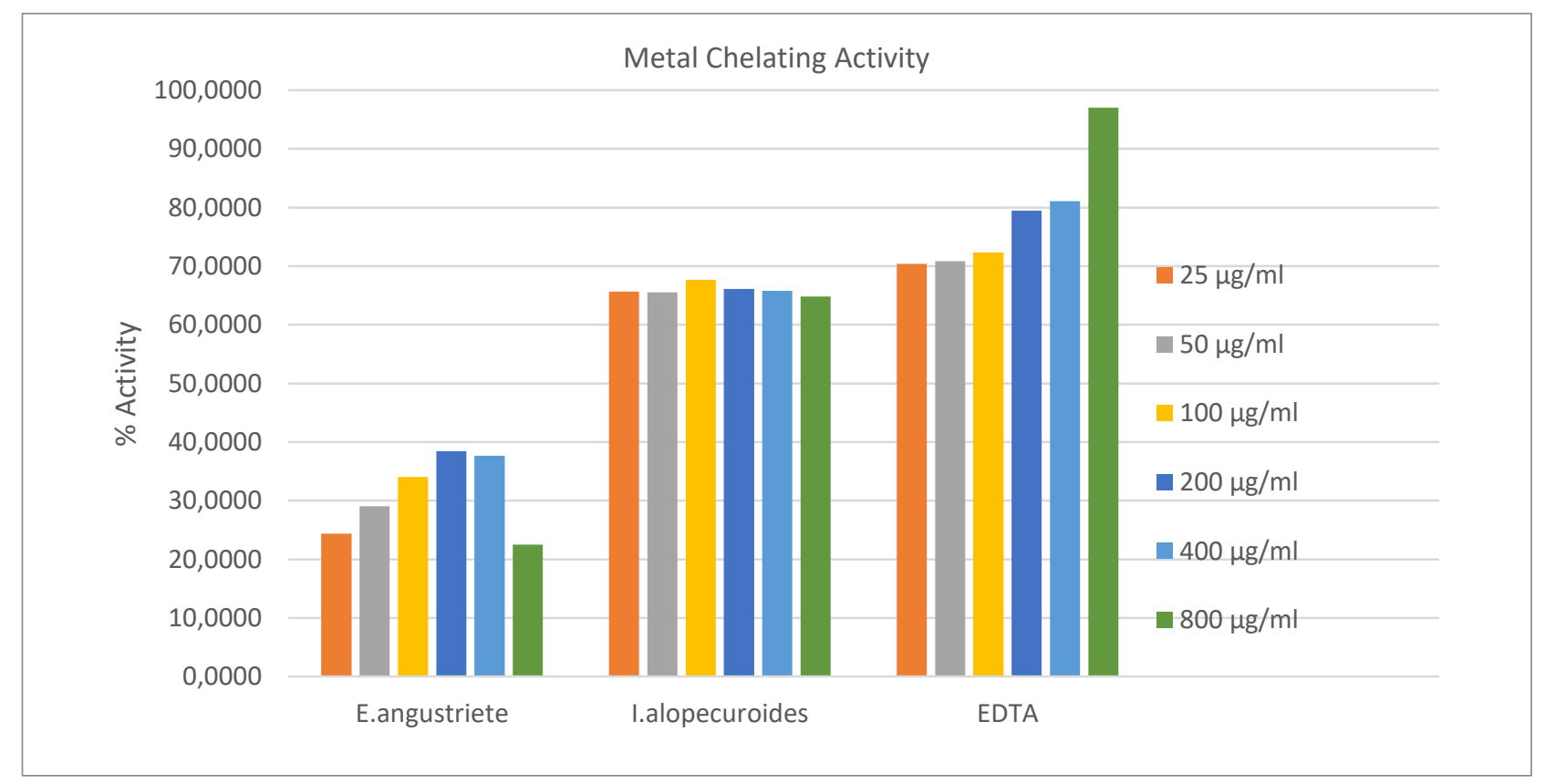


Figure 2. DPPH ${ }^{\bullet}$ activity of essential oil

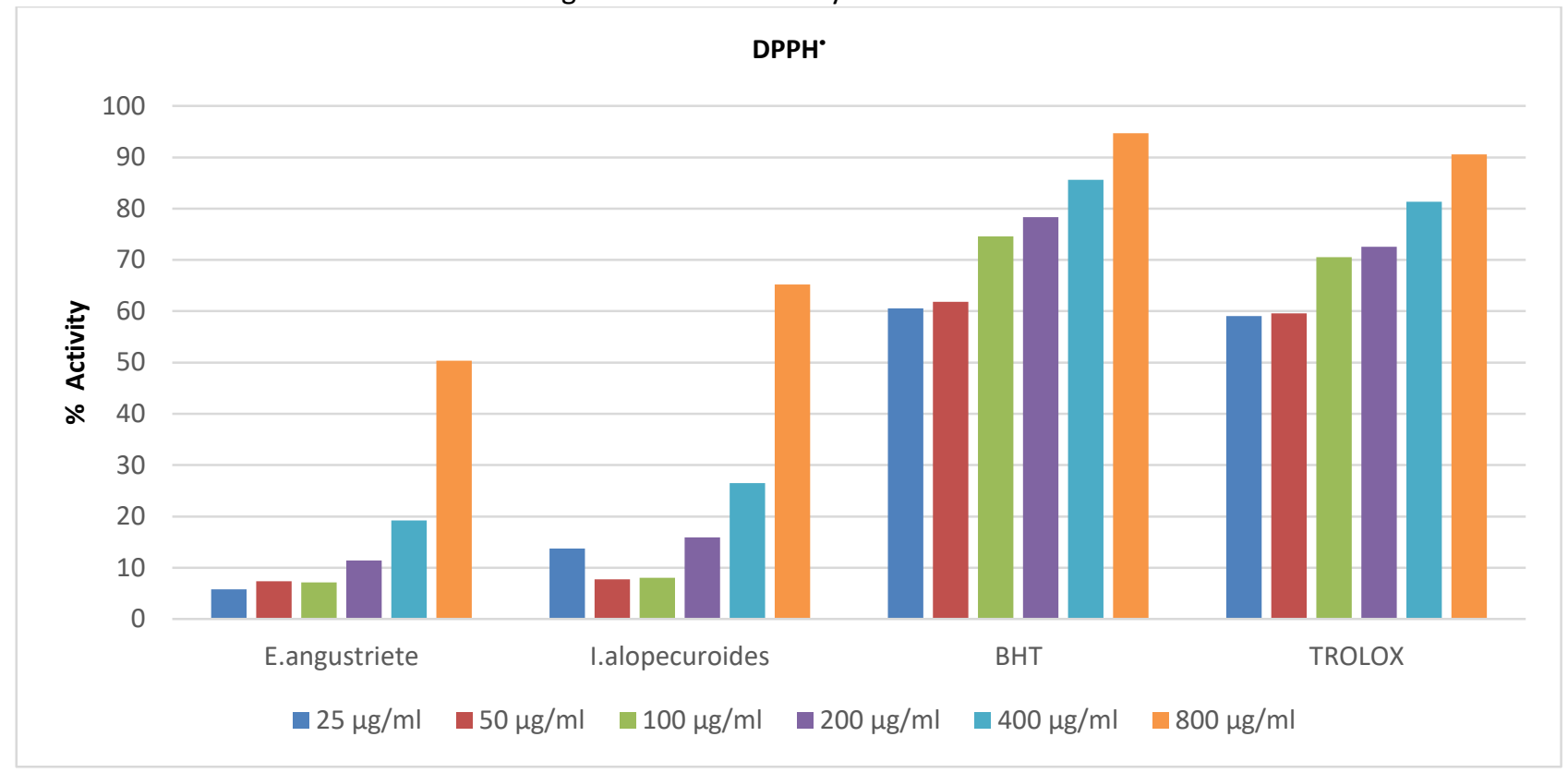

\section{Antimicrobial activity of essential oils}

The essential oils showed moderate antibacterial activity against 3 gram-positive (S. aureus, E. faecalis and $S$. mutans) and 2 gram-negative bacteria (E. coli and $P$. aeruginosa). The $\%$ inhibition values of essential oils from five species against determined in a broth microdilution assay, as shown in Table 3. According to the results, essential oils from each species showed a potent inhibitory effect on the growth of microorganisms without significant differences between groups.

Table 3. Minimal inhibitory concentrations $(\mu \mathrm{g} / \mathrm{mL})$ of essential oils against.

\begin{tabular}{lll}
\hline Microorganisms & Sample & \% $^{\text {Inhibition }}{ }^{\text {a }}$ \\
\hline E. coli ATCC 25922 & E. angustirete & $95.36 \pm 0.14$ \\
E. faecalis ATCC 29212 & I. alopecuroides & $94.26 \pm 0.03$ \\
S. mutans & I. angustirete alopecuroides & $94.23 \pm 0.15$ \\
& E. angustirete & $94.15 \pm 0.04$ \\
P. aeruginosa ATCC 27853 & I. alopecuroides & $95.43 \pm 0.06$ \\
& E. angustirete & $94.25 \pm 0.05$ \\
S. aureus ATCC 25923 & I. alopecuroides & $95.38 \pm 0.08$ \\
\hline
\end{tabular}

aValues are given as mean \pm S.D. $(n=3)$ and considered to be significantly different at $p<0.05$.

\section{Conclusion}

The distillation method was developed in Spain and France at the beginning of the 1300s to obtain essential oil, and in the 1550s, new techniques were started to be applied in order to meet the needs of different branches such as pharmacology (Rangahau, 2001). Today, it is applied in modern methods using advanced technology as well as classical distillation methods. These methods include classical methods such as water distillation and solvent extraction and pressing, as well as modern methods such as microwave extraction 
and solid-phase microextraction (Kılıç, 2008). In this study essential oils were obtained from these moss species using the hydro-distillation method. Essential oils are very complex natural mixtures that contain many ingredients in different concentrations.

In this study, it was observed that the essential oil of $I$. alopecuroides represented highly inhibitory effects on microorganism. According to antioxidant activity results, it's DPPH activity and metal chelating capacity values are higher than essential oil of $E$. angustirete (22.84 \pm 8.91 and $65.93 \pm 0.39$, respectively). Biformene exhibits antioxidant properties (Öztürk et al., 2009). Also, according to the antimicrobial activity tests findings, there was no significant difference within moss materials as shown in Table 3 in the inhibition effect against microorganisms.

In a study by Altuner and Çetin (2018), antimicrobial activity chloroform, benzene, diethyl ether, ethanol, methanol, ethyl acetate, $\mathrm{sdH} 2 \mathrm{O}$ and $0.5 \mathrm{M}$ Tris- $\mathrm{HCl}$ buffer $(\mathrm{pH}: 8.0)$ of $I$. alopecuroides extracts were tested against Bacillus subtilis ATCC 6633, Candida albicans ATCC 95071, Escherichia coli ATCC 11230, Escherichia coli 0157:H7, Listeria monocytogenes ATCC 7644, Salmonella enteretidis ATCC 13076, Shigella flexneri (clinical isolate), Staphylococcus aureus ATCC 25923 and Yersinia enterocolitica 03 by disk diffusion, minimum inhibitory concentration test and minimum bactericidal/fungicial concentration tests. According to this study, benzene extract of a sample collected from Aydın was only active against $B$. subtilis, but the sample collected from Muğla was active against B. subtilis, S. aureus, E. coli and $C$. albicans with its different extracts at different ranges. The essential oil of $I$. alopecuroides was determined as a good antimicrobial activity against all microorganisms especially P. aeruginosa ATCC 27853 and E. coli ATCC 25922.

In another study, methanol extract of $I$. alopecuroides, was shown to have an effective antimicrobial effect on $P$. larve isolates (Sevim et al., 2017). Previous studies confirm the high antimicrobial activity values that this species showed in our study.

Also, Altuner (2008) investigated the effect on the antimicrobial activity of moss variety as the third variable in Ph.D thesis study, he found that 32 of 113 moss extracts were bactericidal, 27 were fungicidal, 25 were fungistatic, and 24 were bacteriostatic. Among the studied 20 moss species, he observed that $I$. alopecuroides showed the highest antimicrobial effect. The obtained moss extracts had different effect on microorganisms. The microorganisms least affected by moss extracts were Listeria monocytogenes and $E$. coli.

The essential oil of $I$. alopecuroides contained biformene-diterpene as a major component (Table 1). Diterpenes compounds such as pimaradienes, ortho- or para-quinone and pyhtol have many biological effects for example anticancer, antioxidant, and anti-inflammatory (Bisio et al., 2019; Costa et al., 2014, Reveglia et al., 2018).

Oxygenated monoterpenes consist of a 10 carbon backbone ( 2 isoprene units) structure. These compounds divided into three classes as aliphatic (myrcene, linalool), monocylic (limonene, carvone, menthol) and bicyclic (thujene, $\Delta^{3}$-carene) oxygenated monoterpenes. They are found in many plants and show many biological effects such as antibacterial, antiviral, antimicrobial and anticandidal effects (İşcan, 2017; Hosseinkhani et al., 2015; Taylor et al., 2020). trans-pinocarveol (23.0\%,-) and limonene oxide (1.4\%, 1.8\%) as oxygenated monoterpenes and $\alpha$-pinene (4.3\%, 9.1\%), myrtenal (14.1\%, 1.7\%) monoterpene compounds are major components of essential oils of $I$. alopecuroides (i) and E. angustirete (ii), respectively. In our study, the high antimicrobial effect of the two species containing these oxygenated monoterpenes supports the literature. In addition, the metal ion chelating capacity of the essential oils of E. angustirete (31.01\%) 
and I. alopecuroides (65.93\%), and were high supporting the antioxidant properties of oxygenated monoterpenes in the literature.

Nikolajeva et al. (2012) studied the antimicrobial activity of aqueous and ethanolic extracts of 11 Bryophyta species including Eurhynchium angustirete (Broth.) T. J. Kop. and 9 Marchantiophyta species collected in Latvia were tested against Staphylococcus aureus MSCL 334, Escherichia coli MSCL 332 and Bacillus cereus MSCL 330. The most comprehensive researches were conducted on the effect of water and ethanol extracts of bryophytes on the growth of Staphylococcus aureus. Minimal inhibitory concentration of ethanolic extracts in the indicated interval of concentration of Eurhynchium angustirete was found 10-30 against Staphylococcus aureus. In this study, antimicrobial activity of the essential oil of Eurhynchium angustirete was found against $S$. aureus lower than that against $P$. aeruginosa, E. coli, E. faecalis and $S$. mutans.

In another study, Tosun et al. characterized the essential oil content of E. angustirete grown Artvin, Turkey, and studied its antimicrobial properties (Tosun et al., 2015). According to the results of the chemical composition, hydrocarbons (81.6\%) and monoterpenes (18.3\%) were the major groups in the essential oil and moderate antimicrobial activity against the bacteria $Y$. pseudotuberculosis, $P$. aeruginosa, $S$. aureus, $E$. faecalis, B. cereus and $M$. smegmatis were observed. In our study, the essential oil of this species contained less monoterpene $(15.30 \%)$ and more oxygenated monoterpenes $(25.9 \%)$ and represented highly antimicrobial activity against $P$. aeruginosa, $S$. aureus and $E$. faecalis.

\section{ACKNOWLEDGMENT}

The authors thank Amasya University Research Laboratory for antimicrobial and antioxidant activity.

\section{CONFLICTS OF INTEREST}

The authors have no conflicts of interest to declare.

\section{REFERENCES}

Adams, R. P. (2004). Identification of volatile oil components by gas chromatography/ mass spectroscopy. 4th Ed., Allured publishing Corp., (pp. 1-698), Carol Stream, Illinois.

Alatas, M., Kara, R., Ezer, T., Uyar, G., \& Batan, N. (2015). The epiphytic bryophyte flora and vegetation of ZonguldakGobu village (Northwest Turkey). Pakistan Journal of Botany, 47(4), 1439-1449.

Altuner E. M. (2008). Determining antimicrobial activity of some mosses, Ph.D. Thesis, Natural and Applied Sciences, Department of Biology, Ankara University, Ankara, Turkey.

Altuner, E. M., \& Çetin, B. (2018). Antimicrobial activity of Isothecium alopecuroides and potential effect of some climate elements on the activity of this bryophyte sample. Kastamonu University Journal of Forestry Faculty, 18(2), 126-137.

Asakawa, Y., \& Ludwiczuk, A. (2017). Chemical constituents of bryophytes: structures and biological activity. Journal of Natural Products, 81(3), 641-660.

Baskaran, G., Salvamani, S., Ahmad, S. A., Shaharuddin, N. A., \& Pattiram, P. D. (2015). HMG-CoA reductase inhibitory activity and phytocomponent investigation of Basella alba leaf extract as a treatment for hypercholesterolemia. Drug Design, Development and Therapy, 9, 509-517.

Bisio, A., Pedreeli, F., D’Ambola, M., Labanca, F., Schito, A. M., Govaerts, R., Tommasi N., \& Milella, L. (2019). Quinone diterpenes from Salvia species: chemistry, botany, and biological activity. Phytochemistry Reviews, 18, 665-842. 
Budke, J. M., Bernard, E. C., Gray, D. J., Huttunen, S., Piechulla, B., \& Trigiano, R. N. (2018). Introduction to the special issue on bryophytes. Critical Reviews in Plant Sciences, 37(2-3), 102-112.

Chen, F., Ludwiczuk, A., Wei, G., Chen, X., C.Stotler, B., \& Bowman, J. L. (2018). Terpenoid secondary metabolites in bryophytes: chemical diversity, biosynthesis and biological functions. Critical Reviews in Plant Sciences, 37(2-3), 210231.

Cheng, X., Xiao, Y., Wang, P., Wang, X., Zhou, Y., Yan, H., \& Liu, Q. (2013). The ethyl acetate fraction of Polytrichum commune L. ex Hedw induced cell apoptosis via reactive oxygen species in L1210 cells. Journal of Ethnopharmacology, 148(3), 926-933.

Costa, J. P., Oliveira, G. A. L., Almeida, A. A. C., Islam, M. T., Sousa, D. P. \& Freitas, R. M. (2014). Anxiolytic-like effects of phytol: possible involvement of GABAergic transmission. Brain research, 1547, 34-42.

Çelik, G. (2020). Antimicrobial Properties and Chemical Composition of the Essential Oil of Leucobryum glaucum (Leucobryaceae). Anatolian Bryology, 6(2), 112-118.

Demetzos, C., Dimas, K., Hatziantoniou, S., Anastasaki, T., \& Angelopoulou, D. (2001). Cytotoxic and anti-inflammatory activity of labdane and cis-clerodane type diterpenes. Planta Medica, 67(07), 614-618.

Devappa, R. K., Makkar, H. P., Becker, K., \& Jatropha, D. (2011). Diterpenes: a Review. Journal of the American Oil Chemists Society, 88(3), 301-322.

Glime, J. M. (2007). Economic and ethnic uses of bryophytes. In: Flora of North America Editorial Committee. (Ed.) Flora of North America North of Mexico vol. 27. Bryophytes part 1. pp. 14-41. Oxford University Press, New York, NY: Oxford.

Harborne, J. B. (1998). Phytochemical Methods: a Guide to Modern Techniques of Plant Analysis. pp. 1-36, 5th Edition, Chapman \& Hall Ltd, London.

Hosseinkhani, F., Jabalameli, F., Banar, M., Abdellahi, N., Taherikalani, M., Leeuwen, W. B. V., \& Emaneini, M. (2016). Monoterpene isolated from the essential oil of Trachyspermum ammi is cytotoxic to multidrug-resistant Pseudomonas aeruginosa and Staphylococcus aureus strains. Revista da Sociedade Brasileira de Medicina Tropical, 49(02), 172-176.

İşcan, G. (2017). Antibacterial and anticandidal activities of common essential oil constituents, Records of Natural Products, 11(4), 374-388.

Jomova, K., \& Valko, M. (2011). Advances in metal-induced oxidative stress and human disease. Toxicology, 283(2-3), 65-87.

Kalaimagal, C. (2019). Identification of bioactive compounds in flower of Tabernaemontana divarıcata (L.) using gas chromatography-mass spectrometry analysis. Asian Journal of Pharmaceutical and Clinical Research, 12(9), 129-132.

Kılıç, N. (2008). Methods of essential oil production. Journal of Bartın Faculty of Forestry, 10(13), 37-45.

Lahlou, S., Correia, C. A., Santos, M. V., David, J. M., David, J. P., Duarte, G. P., \& Magalhães, P. J. C. (2007). Mechanisms underlying the cardiovascular effects of a labdenic diterpene isolated from Moldenhawera nutans in normotensive rats. Vascular Pharmacology, 46(1), 60-66.

Limpens, J., Bohlin, E., \& Nilsson, M. B. (2017). Phylogenetic or environmental control on the elemental and organochemical composition of Sphagnum mosses? Plant Soil, 417, 69-85.

Matos, T. M., Peralta, D. F., Roma, L. P., \& Santos, D. Y. A. C. (2021). The morphology and chemical composition of cuticular waxes in some Brazilian liverworts and mosses. Journal of Bryology, 43(2), 129-137.

Onbaslı D., \& Yuvalı G. (2021). In vitro medicinal potentials of Bryum capillare, a moss sample, from Turkey. Saudi Journal of Biological Sciences, 28(1), 478-483. 
Önder, A., \& Özenoglu, H. (2019). Evaluation of Cytotoxic Effects on Ethereal Extracts of Some Selected Liverworts. FABAD Journal of Pharmaceutical Sciences, 44(2), 119-12.

Öztürk, M., Kolak, U., Duru, M. E., \& Harmandar, M. (2009). GC-MS analysis of the antioxidant active fractions of Micromeria juliana with anticholinesterase activity. Natural Product Communications, 4(9), 1271-1275.

Rangahau, M. K. (2001). Essential oils and their production. Crop and Food Research, Nr. 39, October. Rowe, J. W., 1989. Natural Products of Woody Plants Vol.2, Germany, Springer.

Reveglia, P., Cimmino, A., Masi, M., Nocera, P., Berova, N., Ellestad, G., \& Evidente, A. (2018). Pimarane diterpenes: natural source, stereochemical configuration, and biological activity. Review Article Chirality, 30(2), 1115-1134.

Sert, E., Ugur, A., Ozden, B., Sac, M. M., \& Camgöz, B. (2011). Biomonitoring of ${ }^{210} \mathrm{Po}$ and ${ }^{210} \mathrm{~Pb}$ using lichens and mosses around coal-fired power plants in Western Turkey. Journal of Environmental Radioactivity, 102(6), 535-542.

Sevim, E., Baş, Y., Çelik, G., Pınarbaş, M., Bozdeveci, A., Özdemir, T., \& A.Karaoğlu, Ş. (2017). Antibacterial activity of bryophyte species against Paenibacillus larvae isolates. Turkish Journal of Veterinary and Animal Sciences, 41(4), 521531.

Singh, M., Pal, M., \& Sharma, R. P. (1999). Biological activity of the labdane diterpenes. Planta Medica, 65(01), 2-8.

Stojković, D., Soković, M., Glamočlija, J., Džamić, A., Ristić, M., Fahal, A., \& Petrović, S. (2008). Susceptibility of three clinical isolates of Actinomodura madurae to $\alpha$-pinene, the bioactive agent of Pinus pinaster turpentine oil. Archives of Biological Sciences, 60(4), 697-701.

Sun, S. Q., Wang, D. Y., He, M., Li, X. Y., \& Zhang, C. (2007). Retention capacities of several bryophytes for Hg(II) with special reference to the elevation and morphology of moss growth. Environmental Monitoring and Assessment, 133(13), 399-406.

Taylor, D. J. R., Hamid, S. M., Andres, A. M., Saadaeijahromi, H., Piplani, H., Germano, J. G., Song, Y., Savannah, S., Feuer, R., Pandol, S. J., \& Sin, J. (2020). Antiviral effects of menthol on coxsackievirus B, Viruses, 12(4), 373-388.

Tosun, G., Yayli, B., Özdemir, T., Batan, N., Bozdeveci, A., \& Yayli, N. (2015). Volatiles and antimicrobial activity of the essential oils of the mosses Pseudoscleropodium purum, Eurhynchium striatum and Eurhynchium angustirete grown in Turkey. Records of Natural Products, 9(2), 237-245.

Üçüncü, O., Cansu, T. B., Özdemir, T., A. Karaoglu, S., \& Yayli, N. (2010). Chemical composition and antimicrobial activity of the essential oils of mosses (Tortula muralis Hedw., Homalothecium lutescens (Hedw.) H. Rob., Hypnum cupressiforme Hedw. and Pohlia nutans (Hedw.) Lindb.) from Turkey. Turkish Journal of Chemistry, 34, 825-834.

Vollár, M., Gyovai, A., Szucs, P., Zupkó, I., Marschall, M., C. Löffler, B., Bérdi, P., Vecsernyés, A., Csorba, A., L. Busa, E., Urbán, E., \& Csupor, D. (2018). Antiproliferative and antimicrobial activities of selected bryophytes. Molecules, 23, 1520-1535.

Yushin, N., Chaligava, O., Zinicovscaia, I., Vergel, K., \& Grozdov, D. (2020). Mosses as bioindicators of heavy metal air pollution in the lockdown period adopted to cope with the COVID-19 pandemic. Atmosphere, 11(11), 1194-1204. 